Artigo Especial

\title{
Genotyping of Kell, Duffy, Kidd and RHD in patients with $\beta$ Thalassemia
}

\author{
Lilian Castilho ${ }^{1}$ \\ Maria Rios ${ }^{2}$ \\ Jordão Pellegrino $\mathrm{Jr}^{1}$ \\ Maria H. M. Carvalho \\ Fernando L. Alberto ${ }^{1}$ \\ Sara T.. Saad $^{1}$ \\ Fernando F. Costa ${ }^{1}$
}

\begin{abstract}
Determination of Rh, Kell, Duffy and Kidd phenotypes in addition to ABO is used to prevent the alloimmunization to red blood cells (RBCs) antigens and as part of the antibody identification process in patients with $\beta$ Thalassemia. However, phenotyping in these patients can be time consuming and difficult to interpret. In these situations, it would be valuable to have an alternative to hemagglutination tests to determine the patient's antigen profile. We used PCR-RFLP to genotype such patients.

DNA was prepared from 50 patients with $\beta$ Thalassemia who had been phenotyped by routine hemagglutination, and tested for Kell, Kidd, Duffy/ GATA mutation by PCR-RFLP. RHD/non-D was analysed by PCR product size associated to RHD gene sequence in intron 4 and exon 10/3'UTR. The genotyping assays were performed without knowledge of phenotype results. For RHD/non-D, 47 were RhD+ and RHD+/RHCE+, and 3 were RhD- and RHD-/RHCE+. For Kell, 48 kk were K2K 2 and 2 Kk were K1K2. For Duffy, of 44 samples that had normal GATA box, 8 Fy $(a+b-)$ were FYA/FYA, 15 $\mathrm{Fy}(a+b+)$ were FYB/FYB, and $19 \mathrm{Fy}(a+b+)$ were FYA/FYB; of the other 4 samples 3 were FYA/FYB and heterozygous GATA mutation, and 1 Fy(a-b-) was FYB/FYB, homozygous GATA mutation. Two samples phenotyped as Fy $(a+b-)$ that had normal GATA, presented the 265T/298 ${ }^{A}$ mutations and two samples phen otyped as Fy(a-b+) were gen otyped was FYA/FYB.. For Kidd , $15 \mathrm{Jk}(\mathrm{a}+\mathrm{b})$ were JKA/JKA, $12 \mathrm{Jk}(\mathrm{a}-\mathrm{b}+)$ were JKB/JKB, and $20 \mathrm{Jk}(\mathrm{a}+\mathrm{b}+)$ were JKA/JKB. Three samples phen otyped as JK $(a+b+)$ were gen otyped as JKB/JKB. Genotype is more accurate than phenotype for determination of blood groups in polytransfused patients with $\beta$ Thalassemia. Genotyping in these patients can be helpful to select antigen-negative RBCs for transfusion.

Rev.bras.hematol.hemoter., 2000, 22(2): 69-76
\end{abstract}

Key-words: Genotyping, blood groups, system

\section{Introduction}

The incidence of alloimmunization to RBC antigens other than $A B O$ and $D$ is particularly high in patients with hemoglobinopathies (1), reaching up to $18 \%$ in patients with $\beta$ Thalassemia who have received transfusion(s)
(2-4). Alloimmunization may cause a variety of problems and dilemmas in long-term medical and transfusional management $(5,6)$. Most of these problems pertain to finding appropriate antigen-negative blood for transfusion to alloimmunized patients.

Programs to prevent alloimmunization to

1 - Hemocentro Unicamp, Campinas, SP, Brasil

2 - New York Blood Center, New York, N.Y. USA

Correspondência para: Lilian Castilho

castilho@unicamp.br

Prêmio Oswaldo Mellone de melhor trabalho em Hemoterapia do XXIV Congresso Brasileiro de Hematologia. Rio de Jan eiro, maio de 2000 
RBC antigens have been designed and implemented to provide antigen-matched RBC transfusions to patients with Thalassemia, particularly those who are alloimmunized and/ or in need of chronic transfusion support (7, 8). In addition to $A B O, R B C s$ are phenotyped for Rh, Kell, Duffy and Kidd prior to transfusion aiming both to prevent the alloimmunization to these RBC antigens, and as part of the antibody identification process (9).

Cell typing is essential in sensitized patients in order to confirm the identity of suspected alloantibodies, and to facilitate the identification of antibodies that may be formed in the future. However, accurate phenotyping of RBCs from transfused patients with Thalassemia is a very complex process due to the presence of transfused donors RBCs in the circulation of the recipient. Thus, in these patients phenotyping can be time consuming and difficult to interpret. It is also complicated to type cells when a patient's RBCs have a positive direct antiglobulin test and no direct agglutinating antibody is available.

The DNA technology led to the understanding of the molecular basis of many blood group antigens. The majority of blood group polymorphisms are associated with a single point mutation in the gene encoding the protein carrying the blood group antigen $(10,11)$. This knowledge allows the use of DNA testing to predict the blood group antigen profile of na individual, and that can be used to overcome the limitations of hemagglutination assays.

Several assays for blood group genotyping of patients have recently been developed with the goal of reducing risk or helping in the assessment of the risk of hemolytic disease of the newborn. However, these assays have not been generally applied to the genotyping of patients who have received recent or chronic transfusion care.

The dilema of using DNA obtained from a transfused patients' white blood cells (WBC) is that the donor leucocytes contained in the transfused units could, at least theoretically, interfere with genotyping results $(12,13,14)$. However, studies performed with patient's WBC samples have shown that these cells can be used reliably to determine a blood group polymorphism by polymerase chain reaction (PCR)-based assays even when blood samples from recently transfused patients are used as the source of DNA $(15,16)$. This study demonstrates that post-transfusion blood samples can be safely used for genotyping blood groups. That eliminates the need to use current time-consuming and frequently ineffective methods that involve separation of patient reticulocytes from donor mature RBCs.

We performed genotype assays and correlated the results with phenotype results for the blood groups RH D, KEL, JK and FY using WBCs from polytransfused patients with $\beta$ Thalassemia. We also report here that WBCs can be reliably employed as source of DNA for PCR-based assays for blood group genotyping in transfused patients with $\beta$ Thalassemia as compared against PCR results obtained from other cell source of DNA. Moreover, we observed that genotype is more accurate than phenotype for determination of blood groups in polytransfused patients with $\beta$ Thalassemia.

\section{Methods}

Samples: Blood samples and buccal epithelial cells were collected from each patient after informed consent was given to the health care physician or specialized nurse.

Blood samples: We studied samples from 50 patients with $\beta$ Thalassemia who have been given transfusions of antigen-matched RBC units at the Hemocentro (Unicamp, Campinas, Brazil). These patients had been transfused at least 3 occasions and their blood samples were phenotyped at the time of each transfusion. The most recent blood sample from each patient was also genotyped for RHD, KEL, JK and FY. Blood samples from 100 normal blood donors who had been previously phenotyped for Rh, Kell, Kidd and Duffy were tested as controls.

Buccal epithelial cells: Buccal epithelial cells samples were tested for the patients whom had phenotype/genotype discrepancies. We obtained buccal epithelial cells by wiping the mouth mucosa with a cotton wool swab. 
Agglutination tests: At all times phenotypes were determined by hemagglutination in gel cards (Diamed AG, Morat, Switzerland) using two anti-sera sources.

DNA preparation: DNA was extracted from blood samples using either the phenolchloroform method (17) or the Easy DNA Kit (Invitrogen, Carlsbad, CA) according to the manufacturer's recommendations. DNA from buccal epithelial cells contained in the cotton wool swabs was extracted by the Easy DNA Kit according to manufacturer's protocol \#3.

Polymerase chain reaction (PCR) amplification: The primers and amplification conditions used, were the same as previously published $(15,16)$. Briefly, the PCR was performed with $100-200$ ng of DNA, 50 pmole of each primer, 2 nmole of each dNTP, $1.0 \mathrm{U}$ Taq DNA polymerase and buffer in a final volume of $50 \mu \mathrm{l}$. The PCR analysis for the presence of RHD was performed in two genomic regions, intron 4 and exon 10, as previously described (16). For intron 4, three primers (RHI41, RHI42 and RHI43) yielded a product of 115 bp for RHD and 236 bp for RHCE. For exon 10, a common 5'primer (EX10F) was used for both RHD and RHCE. When paired with the RHD-specific 3'-untranslated region (UT) primer (RHD3UT), it produced a product of $245 \mathrm{bp}$, and when paired with the RHCEspecific 3'-UTR (RHCE3UT), it yielded a product of $160 \mathrm{bp}$ (Figure 1).

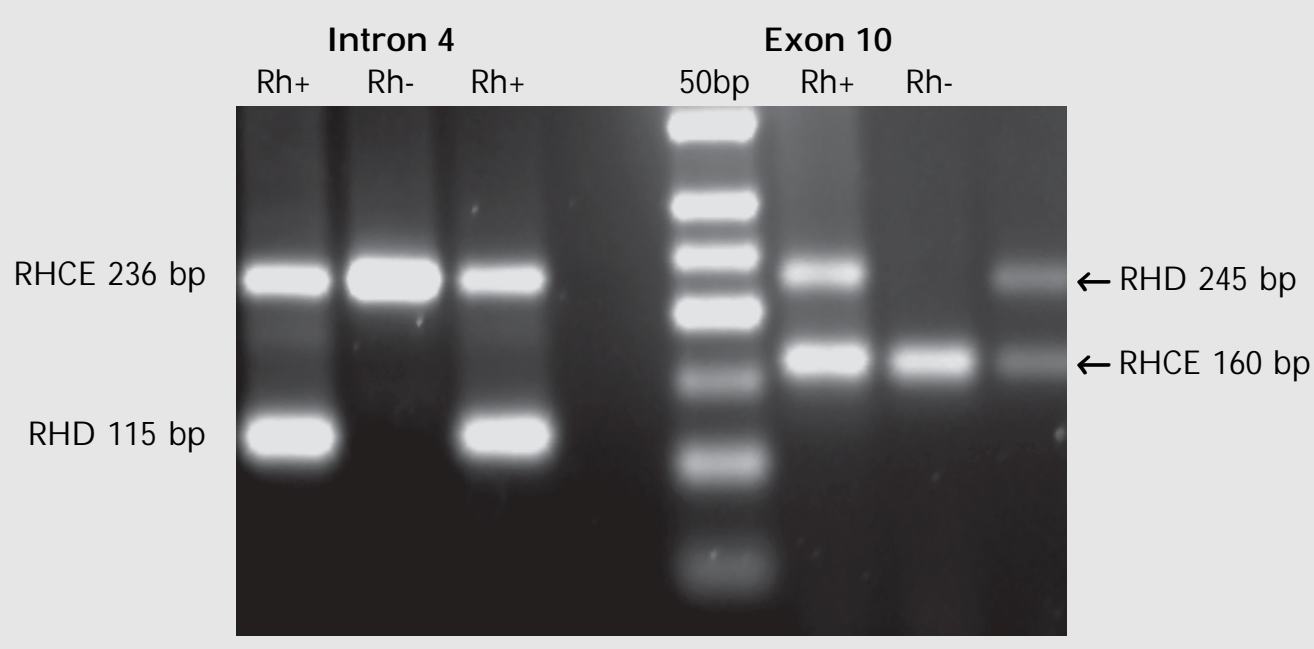

Figure 1. RH D genotyping

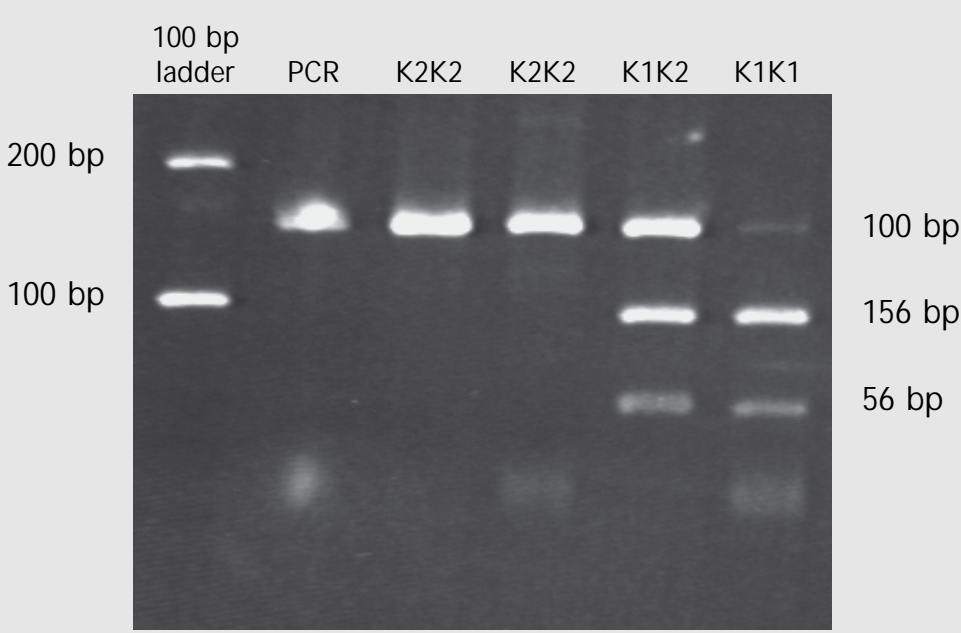

Figure 2. Kell genotyping 


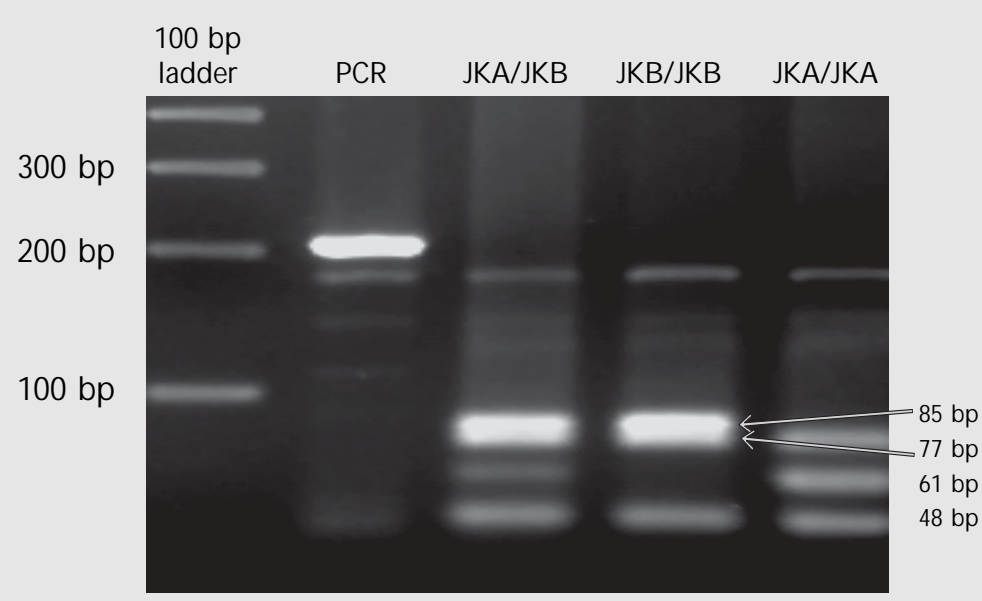

Figure 3. Kidd genotyping

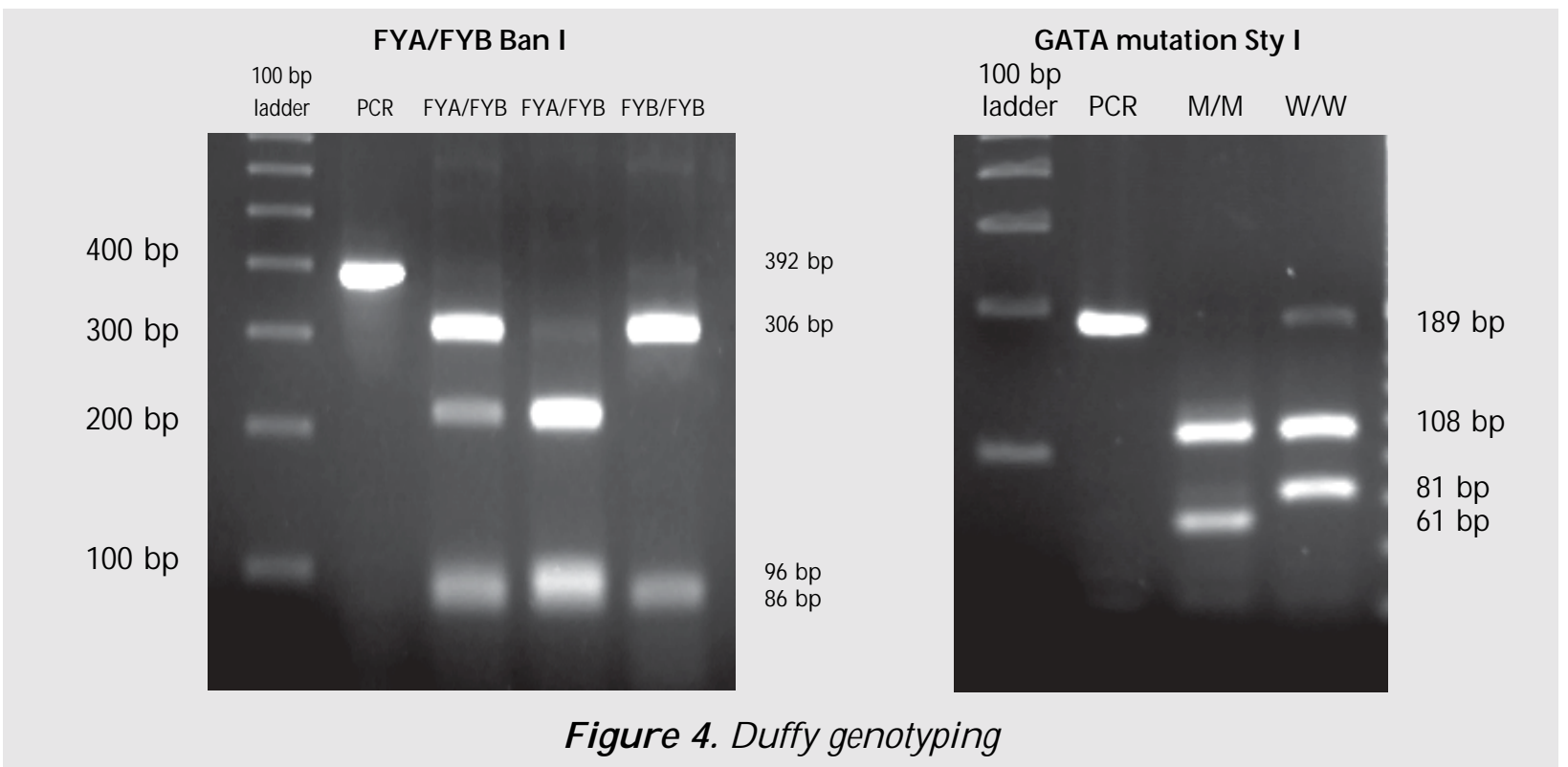

RFLP analysis: The PCR amplified products were digested overnight with the appropriate restriction enzymes (MBI Fermentas, Amherst, NY or New England Biolab, Beverly, MA), in a final volume of $20 \mathrm{ml}$ using $10 \mathrm{ml}$ of amplified product and enzyme in $1 x$ buffer according to manufacturer's instructions.

The enzymes Bsm I, MnI I and Ban I were used to determine, respectively $\mathrm{KEL} 1$ / KEL $2(698 C>T)$, JK A/JK B $\left(838^{A}>G\right)$ and $F Y$ A/ FY B (125 G>A) (18-22). (Figures 2, 3, 4) Furthermore, the Sty I enzyme was used to distinguish between normal and mutated
GATA-1 binding motif $(-33 T>C)$, because the GATA-1 binding site is critical for expression of $\mathrm{Fy}^{\mathrm{b}}$ protein in the red cell membrane (23) (Figure 4).

\section{Results}

Correlation between phenotype and genotype of the 50 patients with $\beta$ Thalassemia were as follows for each blood antigen studied: Phenotype and genotype results from the patients with $\beta$ Thalassemia are shown in table 1. Among the 50 patients, 5 had phenotype/genotype discrepancies. 
Presence or absence of RHD: 47 of the 50 samples were both phenotyped and genotyped as RhD-positive (had amplified product from both RHD and RHCE) and 3 samples phenotyped and genotyped as RhD-negative (had amplified product from RHCE but not from RHD).

Kell: we observed $100 \%$ correlation between phenotype and genotype results for Kell: 48 samples phenotyped as $\mathrm{k} / \mathrm{k}$ were genotyped as $\mathrm{K} 2 / \mathrm{K} 2$ and two samples phenotyped as K/k were genotyped as $\mathrm{K} 1 / \mathrm{K} 2$.

Kidd: phenotype/ genotype did not correlate in 3 of the 50 samples, as they phenotyped as $\mathrm{Jk}(a+b+)$ and genotyped as JKB/JKB.

Duffy: 44 samples had normal GATA box, 8 Fy $(a+b-)$ were FYA/FYA, 15 Fy $(a-b+)$ were FYB/FYB, $19 \mathrm{Fy}(a+b+)$ were FYA/FYB and two samples phenotyped as $\mathrm{Fy}(\mathrm{a}+\mathrm{b})$ were $\mathrm{Fy}^{\mathrm{x}}$ and, presented the 265T and 298A mutations. Of the other 4 samples 3 Fy $(a+b-)$ were FYA/FYB and heterozygous GATA mutation, 1 Fy(a-b-) was FYB/FYB and homozygous GATA mutated. The two discrepant samples phenotyped as Fy $(a b+)$ and were genotyped as FYA/FYB, homozygous GATA mutation.

Correlation between phenotype and genotype of the 100 volunteer blood donors control:

In this group was observed an agreement of $100 \%$ for all blood groups studied.
Genotypes results obtained on DNA from buccal cells and WBCs from the 6 patien ts whom had phenotype/genotype discrepancies:

In order to demonstrate the absence of microchimerism in discrepant results, all 5 patients with phenotype/genotype discrepancies results had the DNA from buccal cells tested by PCR-RFLP, and the results were identical to those obtained when tests were performed using DNA from blood samples.

\section{Discussion}

This study shows the relevance of performing molecular analysis for the determination of blood groups in transfusion dependent patients such as patients with $\beta$ Thalassemia. By employing PCR-RFLP assays we have shown that as expected there is mistyping when hemagglutination is performed to determine the blood group of multitransfused patients. As observed in genotype and phenotype results correlation of the 50 transfused patients studied, phenotype/genotype discrepancies were found in 5 cases.

We confirmed previous study observations that DNA prepared from blood samples collected from a patient who has recently

Table 1: Genotyping results for, RH, KEL, KIDD and DUFFY in samples from 50 patients with $\beta$ Thalassemia

\begin{tabular}{|c|c|c|c|c|}
\hline \multicolumn{1}{c|}{ Genotype } & \multicolumn{4}{|c}{ Phenotype } \\
\hline Rh System & RhD+ & RhD- & \\
\hline RHD+/RHCE+ & 47 & 0 & & \\
RHD-/RHCE+ & 0 & 3 & & \\
\hline Kell System & K+k+ & K-k+ & \\
\hline K1K2 & 2 & 0 & & \\
K2K2 & 0 & 48 & Jk(a-b+) & \\
\hline Kidd System & Jk(a+b-) & Jk(a+b+) & 0 & \\
\hline JKA/JKA & 15 & 0 & 0 & Fy(a-b-) \\
JKA/JKB & 0 & 20 & 12 & 0 \\
JKB/JKB & 0 & 3 & $\mathbf{F y}(\mathbf{a} \mathbf{b}+\mathbf{+})$ & 0 \\
\hline Duffy System & Fy(a+b-) & Fy(a+b+) & 0 \\
\hline FYA/FYA (T/T) & 8 & 0 & 0 & 0 \\
FYA/FYB (T/T) & 0 & 19 & 15 & 1 \\
FYA/FYB (T/C) & 3 & 0 & 0 & 0 \\
FYB/FYB (T/T) & $2 *$ & 0 & 0 \\
FYB/FYB (C/C) & 0 & 0 & & \\
\hline
\end{tabular}

${ }^{*} \mathrm{Fy}^{\mathrm{X}} 265 \mathrm{~T}, 298^{\mathrm{A}}$ 
received a transfusion, can be used for blood group genotyping without risk of detecting microchimerism (16).

The relevance of performing molecular tests in transfusion dependent patients is well illustrated in the Duffy system. In the presence of nomal GATA-1 binding motif, phenotypes and genotypes agree, but when the GATA-1 motif is mutated a pseudo-discrepancy is observed. That is due to the absence of the FY gene expression in the erythroid lineage. However, patients carrying such phenotypes do not need blood units of negative phenotype, once that this protein is expressed in other body tissues, thus recognized as self. This small change in blood type requirement increases the availability of special blood types for such patiens. GATA mutation in our population has only been associated with the FY B allele, however, it has been found associated with the FY A allele in population from Papua New Guinea (24). O ur study also identified two true discrepant samples. Their hemagglutination results were $F y(a-b+)$ and their genotype results were FY A/FY B. Accordingly, DNA samples obtained from buccal epithelial cells confirmed the genotype obtained from the blood sample. The phenotype performed in segments of the transfused units further confirmed that the Fy $(a b+)$ reflected the donor's blood type. Three samples also presented discrepancy in the Kidd typing. All 3 samples phenotyped as $\mathrm{Jk}(a+b+)$ were genotyped as JKB/JKB. The absence of JK A was confirmed by genotyping DNA samples obtained from buccal epithelial cells, and by performing phenotyping in segments of the transfused units, that the $\mathrm{Jk}(\mathrm{a}+)$ reactivity was due to donors RBCs in the patient's circulation system. These three patients could have been immunized for $\mathrm{Jk}^{\mathrm{a}}$ antigen because they were receiving antigen-matched RBC units based in the phenotyping interpretation.

As previously discussed, the seriousness of the alloimmunization problem has led to recommendations that patients with $\beta$ Thalassemia be transfused with blood of donors whose RBC antigens are more closely matched to those of the recipients (7-9). However, accurate antigen typing in transfused patients is a major problem due to the presence of donor RBCs in patient's circulation. Based on our results and under the test conditions we established, we recommend the addition of blood group genotyping for transfused patients to provide antigen-matched RBC transfusions. However, caution in performing these tests and interpreting results must be exercized, since the PCR-based technique is prone to contamination, and the presence of a particular genotype may not be associated with that antigen expression on the RBC's membrane. Such situations include, the detection of genes with a silencing mutation in a location other than that being analysed (e.g., point mutation in the GATA box), the detection of a gene that is silenced by na alteration of a gene encoding protein with a modifying effect (e.g. Rhmod, Rhnull), or the detection or nondetection of a hybrid gene (25-29). The possibility to have na alternative to hemmaglutination tests to determine the patient's antigen profile should be considered for patients with $\beta$ Thalassemia who need repeated transfusion therapy.

\section{Genotipagem dos sistemas Kell, Duffy, Kidd e RHD em pacientes com $\beta$ Talassemia}

Lilian Castilho, Maria Rios, Jordão Pellegrino Jr, Maria H. M. Carvalho, Fernando L. Alberto, Sara T.O. Saad, Fernando F. Costa

\section{Sumário}

A determinação dos fenótipos Rh, Kell, Duffy e Kidd, associada ao ABO éutilizada para prevenir a aloimunização a antígenos eritrocitários e participam também no processo de identificação de anticorpos nos pacientes com $\beta$ talassemia.

Todavia, a fenotipagem desses pacientes é trabalhosa e de difícil interpretação. Nesta situação, deve ser avaliada uma alternativa ao teste de hemaglutinação para determinar 0 padrão antigênico dos pacientes.

Utilizamos para tal fim o método PCR-RFLP. Foram preparados DNAs de 50 pacientes com $\beta$ talassemia que haviam sido anteriormente fenotipa dos pela hamglutina ção e testados para Kell, Kidd, Duffy/GATA mutação por PCR-RFLP. RHD/não-D foi analisado pelo tamanho do produto, do PCR associado à seqüência do gene RHD no intron 4 e exon 10/3' UTR. 
Os testes de gen otipagem foram realizados sem o conhecimento dos resultados dos fenótipos. Para os RHD/não-D, 47 foram RhD+e RHD+/ RHCE+, e 3 foram RhD- e RHD-/RHCE+.

Para oKell, 48 kk foram K2K2 e2 Kk foram K1K2. Para o Duffy, das 44 amostras que haviam sido normais, GATA box, 8 Fy(a+b-) foram FYA/FYA, $15 \mathrm{Fy}(a+b-)$ foram FYB/FYB e $19 \mathrm{Fy}(a+b+)$ foram FYA/FYB; das outras 4 amostras, 3 foram FYA/ FYB e heterozigoto GATA mutação, e 1 Fy(a-b-) era FYB/FYB, homozigoto GATA mutação.

Duas amostras fen oti padas como Fy( $a+b-)$, que eram normais GATA, a presentavam as mutações $265 T / 298^{A}$ e 2 amostras fen oti pa das como Fy(a$\mathrm{b+})$ haviam sido genotipadas como FYA/FYB. Para o Kidd, 15 Jk( $a+b-)$ foram JKA/JKA, 12 Jk(a$b+)$ foram JKB/JKB, e $20 \mathrm{Jk}(a+b+)$ foram JKA/ JKB. Três a mostras fen otipadas como JK $(a+b+)$ haviam sido gen otipadas como JKB/JKB.

A genotipagem é mais acurada que a fenotipagem para determinação de grupos sangüíneos em pacientes portadores de $\beta$ talassemia politransfundidos. A genotipagem nesses pacientes pode ser importante para selecionar hemácias antigenicamenten egativas para transfusão de glóbulos vermelhos.

Rev.bras. hematol.hemoter., 2000, 22(2): 69-76

Palavras-chave: Genotipagem, grupos sanguínios, sistema

\section{References}

1. Blumberg N, Peck K, Ross K, Avila E. Immune response to chronic red blood cell transfusion. Vox Sang 1983. 44:212-7.

2. Economidou J, Constantoulakis M, Augoustaki $O$, adinolfi $M$. Frequency of antibodies to various antigenic determinants in polytransfused patients with homozygous thalassemia in Greece. Vox Sang 1971. 20:252.

3. Sirchia G, Zanella A, Parravicini A, Morelati $F$, Rebulla P, Masera G. Red cell alloantibodies in patients with thalassemia major. Results of na Italian cooperative study. Transfusion. 1985. 25:110.

4. Spanos T, Karageorga M, Ladis V, Peristeri J, Hatziliami A, kattamis C. Red cell alloantibodies in patients with thalassemia. Vox Sang. 1990. 58:50.
5. Greenwalt TJ, Zelenski KR. Transfusion support for hemoglobinopathies. Clin. Haematol. 1984. 13:151-65.

6. Charache S. Problems in transfusion therapy (editorial). N. Engl.J. Med. 1990. 322: 1666-8.

7. Perkins HA. The safety of the blood supply: making decisions in transfusion medicine. In: Nance SJ, ed. Blood safety: current challenges. Bethesda: American Association of Blood Banks. 1992. 125-150.

8. Coles SM, Klein HG, Holland PV. Alloimmunization in two multitransfused patient populations. Transfusion. 1981. 21: 462-6.

9. Michail-Merianou $\mathrm{V}$, Pamphili-Panouspoulou L, Piperi-Lowes L, Pelegrinis E, Karaklis A. Alloimmunization to red cell antigens in thalassemia: comparative study of usual versus better-match transfusion programmes. Vox sang. 1987. 52: 95.

10. Reid ME, Yazdanbakhsh K. Molecular insights into blood groups and implications for blood transfusions. Current Opinion in Hematology. 1998. 5: 93-102.

11. Avent ND. Human erythrocyte antigen expression: its molecular bases. Br.J. Biom. Sci. 1997. 54: 16-37.

12. Lee TH, Donegan E, Slichter S, Bush MP. Transient increase in circulating donor leucocytes after allogeneic transfusions in Immun ocompetent recipients compatible with donor cell proliferation. Blood. 1995. 85: 1207-14.

13. Adams PT, Davenport RD, Rcardon DA, Roth MS. Detection of circulating donor white blood cells in patients receiving multiple trasnfusions. Blood. 1992. 80: 551-5.

14. Lee T-H, Paglieroni T, O hro H, Holland PV, Bush MP. Longterm multi-lineage chimerism of donor leucocytes in transfused trauma patients. Blood. 1996 (abstr.). 88 (S): $265^{a}$.

15. Rios M, Cash K, Strupp A, Uehlinger J, Reid ME. DNA from urine sediment or buccal cells can be used for blood group molecular genotyping. Immunehematology. 1999. 15: 61-65.

16. Reid ME, Rios M, Powell D, Charles-Pierre D, Malavade V. DNA from blood samples can be used to genotype patients who have recently received a transfusion. 
Transfusion. 2000. 40: 1-6.

17. Davies L, Dibner MD, Battey JF. Basic Methods in Molecular Biology. Elsevier Science Publishing Co. Inc., 1986. New York.

18. Lee S, Wu X, Reid ME, Zelinski T, Redman C. Molecular basis of the Kell (K1) phenotype. Blood. 1995. 85: 912-6.

19. Olivès $B$, Merriman $M$, Bailly $P$, Bain $S$, Barnett A, Todd J, Cartron J-P, Merriman T. The molecular basis of the Kidd blood group polymorphism and its lack of association with type 1 diabetes susceptibility. Hum. Mol. Genet. 1997. 6: 1017-20.

20. Chaudhuri A, Polyakova J, Zbrezezna V, Williams K, Gulati S, Pogo AO. Cloning of glycoprotein D cDNA, which encodes the major subunit of the Duffy blood group system and the receptor for the Plasmodium vivax malaria parasite. Proc. Nat. Acad. Sci. USA 90: 1993. 10793-97.

21. Iwamoto S, O mi T, Kajii E, Ikemoto S. Genomic organization of the glycophorin D gene: Duffy blood group $\mathrm{Fy}^{\mathrm{a}} / \mathrm{Fy}^{\mathrm{b}}$ alloantigen system is associated with a polymorphism at the 44 -amino residue. Blood. 1995. 85: 622-26.

22. Tournamille C, Collin Y, Cartron J-P, Le Van Kim C. Disruption of a GATA motif in the Duffy gene promotor abolishes erythroid gene expression in Duffynegative individuals. Nature Genet. 1995. 10: 224-28.
23. Rios $M$, Reid ME, Naime $D$, Chaudhuri $A$, Pogo AO, Bianco C. Importance of GATA box analysis in genotyping for the Duffy blood group system. Transfusion. 1997 (abstr.). 37(S):101S.

24. Zimmerman PA, Woolley I, Masinde GL, Miller SM, McNamara DT, Hazlett F, Mgone Alpers MP, Genton B, Boatin BA, Kazura JW. Emergence of $F Y^{*} A(n u l l)$ in a Plasmodium vivax-endemic region of Papua New Guinea. Proc Nat Acad Sci. USA. 1999 Nov 23; 96(24): 13973-7.

25. Olsson ML, Hansson C, Akesson IE, Avent ND, Daniels GL. Detection of the common alleles at the Duffy blood group locus by allele-specific primer PCR. Transfusion. 1997 (abstr.). 37(S): 102S.

26. Cartron J-P, Bailly P, Le Van Kim C. Insights into the structureand function of membrane polypeptides carrying blood group antigens. Vox Sang. 1998. 74 (Supl 2): 29-64.

27. Huang $\mathrm{CH}$. Molecular insights into the Rh protein family and associated antigens. Curr Opin Hematol. 1997. 4: 94-103.

28. Huang $\mathrm{CH}$, Blumenfeld 00 . MNSs blood groups and major glycophorins: molecular basis for allelic variation. In: cartron J-P, Pouger $P$, eds $>$ Molecular basis of major human blood group antigens. New York: Plenum Press. 1995. 153-83.

29. Avent ND \& Reid ME. The Rh Blood group system: A review. Blood, 2000. 95:1-13. 